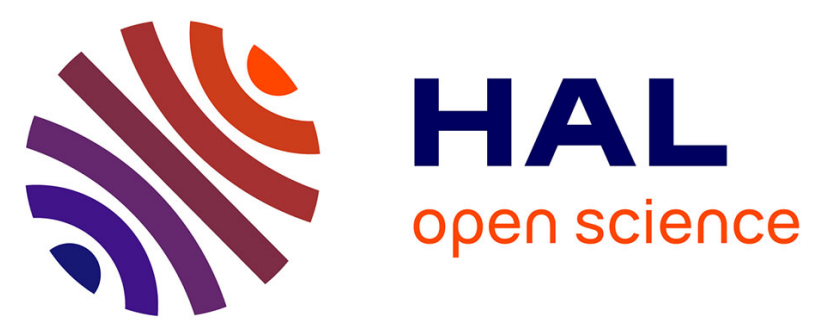

\title{
Prevention of familial transmission of depression: EFFEKT-E, a selective program for emotionally burdened families
}

Anneke Bühler, Charlotte Kötter, Stefanie Jaursch, Friedrich Lösel

\section{To cite this version:}

Anneke Bühler, Charlotte Kötter, Stefanie Jaursch, Friedrich Lösel. Prevention of familial transmission of depression: EFFEKT-E, a selective program for emotionally burdened families. Journal of Public Health, 2011, 19 (4), pp.321-327. 10.1007/s10389-011-0423-5 . hal-00637817

\section{HAL Id: hal-00637817 https://hal.science/hal-00637817}

Submitted on 3 Nov 2011

HAL is a multi-disciplinary open access archive for the deposit and dissemination of scientific research documents, whether they are published or not. The documents may come from teaching and research institutions in France or abroad, or from public or private research centers.
L'archive ouverte pluridisciplinaire HAL, est destinée au dépôt et à la diffusion de documents scientifiques de niveau recherche, publiés ou non, émanant des établissements d'enseignement et de recherche français ou étrangers, des laboratoires publics ou privés. 
Prevention of familial transmission of depression: EFFEKT-E, a selective program for emotionally burdened families

Anneke Bühler ${ }^{1}$, Charlotte Kötter ${ }^{1}$, Stefanie Jaursch ${ }^{2} \&$ Friedrich Lösel $^{23}$

${ }^{I}$ Institut für Therapieforschung, München

Präventionsforschung

Parzivalstr. 25

80804 München, Germany

${ }^{2}$ Universität Erlangen-Nürnberg

Institut für Psychologie

Bismarckstr. 1

91054 Erlangen, Germany

${ }^{3}$ University of Cambridge

Institute of Criminology

Sidgwick Avenue

Cambridge CB3 9DT

United Kingdom

Anneke Bühler, 089-36080483, Fax: 089/36080469, buehler@ift.de 
Prevention of familial transmission of depression: EFFEKT-E, a selective program for emotionally burdened families 
Abstract

Aim: Parental depression is a strong risk factor for depression in children and is associated with offspring's behavioral problems. Therefore, prevention measures should aim to reduce the transmission of risk to children of depressed mothers. In this paper EFFEKT-E (Entwicklungsförderung in Familien: Eltern- und Kinder-Training in emotional belasteten Familien), a prevention program for the setting of mother-child rehabilitation clinics is described and evaluation results are reported. EFFEKT-E is a family-oriented program including a parent training and a child social skills training for pre-school children. Subjects and Methods: The evaluation study contained 375 mothers and their children. The program was evaluated in a quasiexperimental pre-post-follow up design using instruments on parenting behavior and children's emotioanl and behavioral problems. Results: Evaluation showed satisfying reach out and implementation of the program. Compared to a treatment-as-usual condition, EFFEKT-E children exhibited less emotional disruption and hyperactivity. Mother's sense of parental competence was promoted, problematic parenting behavior decreased. Conclusion:EFFEKT-E is an evidencebased selective program which has the potential to prevent intergenerational transmission of depression.

Keywords: selective prevention, family-oriented, depression, behavioral problems, children, depressed mothers 
About $17 \%$ of German citizens develop a depressive disorder during their lifetime (Jacobi et al. 2004). Emotional problems can be observed as early as in pre-school age. A prevalence rate of 6 , $4 \%$ has been estimated for 3 to 6 year old children in Germany (Hölling et al. 2007). During childhood, anxiety and depressive mood rates are equally distributed between girls and boys, but in adolescence a gender difference occurs: Female adolescents report more emotional problems than boys $(10,8 \%$ vs. $6,6 \%)$. In addition, prevalence rates depend on socio-economic and migrant status. More children from families with lower SES or from migrant families suffer from anxiety and depressive mood (Hölling et al. 2007).

Depression produces substantial economic costs (Paykel et al. 2005). Besides the financial load, the individual burden of a child with anxious and depressive behavioral tendencies on his or her way through adolescence to adulthood calls for action. Depressed children have poorer communication and problem-solving skills, and are less supportive and assertive than nondepressed children (Garber 2006). They have less intensive relationships with peers and family members, experience rejection, have less academic skills, and more school problems (Groen and Petermann 2002). Thus, internalizing behaviors impede the accomplishment of nearly all adolescence-specific developmental tasks increasing the probability of lifelong persistent maladaptive development (Groen and Petermann 2002).

Parental depression is one of the strongest risk factors for depression in children (Garber 2006). Compared to children of non-depressed parents, girls and boys in emotionally burdened families are about three to four times more likely to develop a mood disorder, and have an increased risk for initiation of other internalizing behaviors, conduct disorders, school problems, substance abuse disorders and lower overall functioning (Garber 2006). Depressive episodes of children of depressed parents start earlier in life, last longer, are more severe and reoccur more often than those from children without familial vulnerability (Goodman 2007). Behavioral-genetic and environmental studies have provided evidence of both genetic and environmental factors contributing to development of depression (Garber 2006).

Evidence of environmental risk factors guides behavioral prevention efforts. Families with a depressed parent have been described as having more problems with attachment, communication, cohesion, social support, childrearing practices, chronic criticism, harsh discipline, and inappropriate peer-like relationships (Garber 2006). Cognitive tendencies such as less parental self-efficacy, more negative views of themselves as parents and more critical perceptions of their children are characteristics of depressed mothers (Goodman 2007) and play an important role in the interaction between depressed mother and her child (Teti et al. 1996). Goodman (2007) reviewed studies that tried to disentangle the mechanisms mediating between parental depression and emotional or other behavioral problems in childhood. They showed that the psychosocial pathway from parental depression to child maladaptation includes specific impairments in parenting behavior: low levels of parental warmth, high levels of maternal hostility, harsh and 
inconsistent discipline, dysfunctional communication, less social support, worse interaction quality and less maternal social skills (Goodman 2007). Recently, Garber and Cole (2010) confirmed a "launch and grow" type of cascade in which maternal depression is conceptualized as launching a set of risk factors which then in turn predict the growth of children's depression development during adolescence. Garber concludes: “An important next step in the development of depressionprevention programs would be to explicitly target parenting behaviors that are most likely to contribute to depression in children (e.g. harsh, inconsistent discipline, criticism and rejection, withdrawal, intrusiveness). This then could supplement the child-focused components of the intervention that more directly address children's cognitions and coping strategies" (Garber 2006, p.S114).

Existing prevention programs for families with a depressed parent target adolescents. Beardslee and his colleagues $(1997 ; 2003)$ developed a selective prevention program for adolescent offspring of depressed parents. The program showed to be more effective in reducing adolescents' depression than a solely psycho-educative approach with small to moderate effect-sizes at end of intervention and 18 month follow-up. An indicative program for offspring of depressed parents was evaluated by Clarke et al. (2001). The effect sizes for this program were moderate at shortand long-term. Recently, Compas et al. (2009) tested a family cognitive-behavioral preventive intervention for parents with a history of depression and their 9-15-year-old children. The authors compared it with a self-study written information condition in a randomized clinical trial. The family-based measure led to a moderate effect in favourable outcomes for child behaviour. In line with the intervention model, changes in adolescents' coping and positive parenting mediated the effects of the intervention on depressive, internalizing, and externalizing symptoms (Compas et al. 2010). Thus the family-oriented approach is promising. However, there is a lack of research on the effectiveness of family-oriented programs for younger children of selective target groups. Early prevention at preschool age could be particularly promising because these years are crucial for socio-emotional development, which is influenced by familial context (Reichle and Gloger-Tippelt 2007).

The impact of a prevention program does not only depend on effectiveness but also on reach of the target group. Even the most effective approach is useless if motivating the target group to participate fails. Recruitment is an issue in most selective and indicative prevention domains, and due to the nature of the disorder may be even more a problem among depressive populations (Beeber et al. 2007, Pauschardt et al. in press). In order to be successful, an intervention setting needs to attract emotionally burdened families and provide the necessary time and space requirements for a family-oriented program. In Germany, mother-child rehabilitation centers fulfill these conditions. These clinics offer prevention and/or treatment for mothers and fathers with or without diagnosis of somatic or psychosomatic disorders. Studies show that in up to $50 \%$ of women seeking support from these institutions clinically relevant psychological symptoms can be observed (Meixner 2004). More than $80 \%$ of these mothers report depressive mood at the beginning of their rehabilitation stay. A regular stay lasts three weeks, in which psychosocial and 
medical treatment are administered. Mothers are accompanied by their child(ren) which in most cases have not yet developed behavioral or emotional problems.

Within this context we aimed to develop and evaluate a family-oriented program for depressed mothers and their pre-school children. The program should prevent the offspring's emotional and behavioral problems by promoting maternal parenting behavior and children's social-cognitive problem solving skills during their stay in mother-child rehabilitation clinics. This work was supported by a grant from the prevention research program of the German Federal Ministry of Education and Research (BMBF). The project is a cooperation between the IFT Institut für Therapieforschung, Munich, the national welfare organization "Bundesverband Arbeiterwohlfahrt" and their clinics, and the Institute of Psychology at the University of Erlangen-Nuremberg. This paper focuses on the development of the prevention program EFFEKT-E and briefly sums up evaluation research findings. Detailed information about basic assumptions, implementation, and effectiveness of the program can be found elsewhere (Kötter et al. 2009; Kötter et al. 2010; Bühler and Kötter, 2010; Kötter et al. submitted).

\section{Method}

Development of the program

EFFEKT-E is an adaptation of a universal program (EFFEKT ${ }^{\circledR}$, www.effekt-training.de) which trains parenting behavior and children's social competence in order to prevent general child behavioral problems. EFFEKT $^{\circledR}$ was chosen as a basis for the selective program because it is based on theoretically sound concepts, evaluated in controlled studies, and showed desirable effects in universal and selective prevention (Lösel et al. 2006, 2009; Runkel, 2009; Stemmler et al. 2007; Beelmann 2003).

Adaptation was necessary in terms of content and delivery. In order to identify specific risk factors for development of child behavior problems in families with a depressed parent a literature search was conducted. It resulted in reviews and single studies on development of anxiety and depression in children and adolescents, on parental depression as well as on depression prevention approaches Most studies stem from US-research groups. There was no need to add elements with regard to development of externalizing problems as the original program EFFEKT ${ }^{\circledR}$ focusses on this domain. Adapting the program to the setting of a mother-child clinic included a survey among 15 initially interested clinics which informed about realistic and sustainable implementation conditions (number of sessions, length and timing of sessions, mediators of program).

Implementation and Evaluation

An evaluation study was carried out in 13 mother-child-clinics in Germany. A quasi-experimental design was implemented that contained a pre-post and follow-up comparison with an equivalent control group (cohort design, see figure 2) Data of the control group of mother-child-dyads were collected in clinics first (TAU treatment as usual condition). During their three week's stay, mother-specific rehabilitation included various medical and psychosocial treatment but no family- 
oriented parenting program. Children did not receive special treatment but spent their time in day care. Afterwards clinic staff was trained to deliver the program in the subsequent treatment phase. Mothers and children in the training group participated in the usual clinic procedures plus the EFFEKT-E-training for mothers and children.

A total of 2379 mothers were admitted to the clinics during the study interval in 2007 (treatment group (TG) and control group (CG)). At arrival, a mother was asked to enroll in the study if she (a) had a child aged between four and seven years accompanying her and if she (b) met the criteria for depression (critical value on CES-D (above 16, Radloff 1977) or documented diagnosis of depressive disorder). Screening revealed a subgroup of $33 \%$ depressive mothers, of which $70 \%$ agreed to participate in the study. A retention rate of $69 \%$ was reached over the pretest-posttest and 6 months follow-up period. The sample consisted of 375 families that provided data during the clinic stay. 31 training courses were delivered with numbers of participants ranging from 4 to10 mothers and children respectively.

Mothers completed questionnaires at arrival and end of their three week's stay at the mother-child health resorts ( $\mathrm{t} 0$ and $\mathrm{t} 1$ ) as well as six months later back home (t2). Short German versions of standardized instruments were used for assessing mediating and outcome variables (SBQ Social Behavior Questionnaire, Tremblay 1992). Mothers reported on parenting behavior (APQ Alabama Parenting Questionnaire (Shelton et al. 1996) and cognitions (PSOC Parenting Sense of Competence Scale (Johnston and Mash 1989); PSI Parenting Stress Index (Abidin 1995)) and on children's social behavior and skills (VBV Verhaltensbeobachtungsbogen für Vorschulkinder (Döpfner et al. 1993). For process evaluation purposes, mothers filled in evaluation forms for each training session as well as global ratings at the end of the training. Trainers of the children's program rated children's on-task and off-task behavior during each session. Trainers of both courses also self-rated the quality of implementation of each session. Methodological details are reported in Kötter et al. (2009), Bühler and Kötter (2010), and Kötter et al. (in press).

\section{The EFFEKT-E program}

The new EFFEKT-E-program aims at improving specific risk-factors for development of internalizing and externalizing behaviors in families with a depressed parent. In line with Garber (2006) and Goodman (2007) EFFEKT-E consists of (a) a parenting module which focuses on

- $\quad$ positive parenting and psycho-educative elements to ameliorate mother-role-related depressive cognitions and perceptions,

- $\quad$ adequate discipline techniques,

- coping in depression-specific stress situations including seeking for social support and (b) a child training which targets problem solving in order to enhance social-cognitive skills.

Our proposed prevention model is based on Goodman and Gotlib's Integrative Model for the Transmission of Risk to Children of Depressed Mothers $(1999,2002)$ considering selected environmental risk-factors which are highlighted in Figure 1. 
Insert Figure 1 about here

EFFEKT-E is implemented by trainer teams. Clinical psychologists run the parent training, certified social workers are in charge of the child component. Teams participate in two-day training workshops. Materials are available at the University of Erlangen-Nürnberg (www.effekttraining.de).

The EFFEKT-E parent training: The training contains six sessions to be held twice weekly within three weeks (see Table 2 for a short description of each session). Four sessions seek to improve general parenting skills, i.e. principles of positive parenting, requesting cooperation, adequate discipline, and enhancement of the family cohesion and social relations. Two sessions deal with depression-specific content: coping with stressful parenting situations, especially during periods of depression, and dysfunctional thoughts about the maternal role. In order to enhance learning effects, the training incorporates various methods (presentations, group discussions, role plays, home-work, etc.).

The EFFEKT-E child training: Due to setting-specific reasons, the 15 session long original children's training ("I can problem solve", German adaptation by Beelmann et al. 2007) had to be reduced to 6 sessions. The training is a manualized program targeting social problem-solving skills. The content of the training was slightly changed for the selective approach (addition of the emotion "guilt"). A mother-child session was added to exercise problem solving and parenting behavior in the mother-child dyad and facilitate transfer into daily life. Through means of roleplays, question-answer-rounds, active games, pictures and hand puppets, children learn socialcognitive problem-solving skills with an emphasis on the identification of emotions as well as causes and reasons for behavior (see table 3 for a short description of each session).

Insert Table 1 and 2 about here

\section{$\underline{\text { Results }}$}

Within the evaluation study, 31 EFFEKT-E courses were implemented with numbers of participants ranging from 4 to10 mothers and children respectively. The trainings were held by ten different teams who belonged to the staff of the particular mother-child clinic.

Mediation analysis of the baseline data was used to test the prevention model of the program (Kötter et al. 2010). The model was supported by the finding that the association between maternal depression and children's emotional problems was fully mediated by perceived parental stress. Perceived stress partly mediated the relationship between maternal depression and hyperactivity of the child. Unexpectedly, maternal depression did not correlate with parenting behaviors (Kötter et al., 2010). 
With regard to reach of the target group, using mother-child-clinics as an access strategy was successful. On average, participating mothers were 35 years old and had two kids (TG M=35,8 years, of age 1,97 children; CG M=36,2 years of age, 1,99 children, see Bühler and Kötter 2010 for details). About one third were single mothers (TG: 32\%, CG: 32,8\%), more than two thirds were in part- or full-time work (TG: $72,4 \%, \mathrm{CG}: 70,2 \%$ ) and had a monthly income of more than 1.500 Euro (TG: 67,8\%, CG: 69,5\%).About every tenth family had migrant background (TG: 8,3\%, CG: 12,2\%). Mean depression CES-D score was high (TG: M=28,8, CG: M=26,3) at entry of the clinic stay but only about $25 \%$ of patients had already been identified to have a clinical diagnosis of a mood disorder (TG: 25,5\%, CG: 26,5\%). Children's mean age was 5,3 years (TG: $\mathrm{M}=5,3, \mathrm{CG}: \mathrm{M}=5,32$ ) and $45 \%$ were female (TG: 44,5\%, CG: 45,8\%). Nearly all children were in child care or first grade of school (TG: $99,3 \%$, CG: $98,4 \%$ ). More than $75 \%$ of the mothers reported that their child had not yet needed treatment due to psychosocial problems (TG: $81,4 \%$ CG:76,3\%). There were no significant differences between the treatment and control sample. Thus due to the pretest-equivalence of the groups and the clinically relevant level of depression of the sample far beyond the critical value of the CES-D (Radloff 1977) testing the effectiveness hypothesis seems appropriate.

Implementation and acceptance of the training content was satisfying. Contents were nearly completely realized in the parent and child component. With regard to implementation quality, $77 \%$ of the trainers stated on average, that they could implement the sessions very successfully or successfully. Children's training was seen as being implemented very successfully or successfully by $97 \%$ of program facilitators (Kötter et al. 2009). Process evaluation data showed that mothers were satisfied with the content and composition of the parent training. In general they rated the program content as very helpful. Children actively participated and enjoy their seven EFFEKT-E sessions (Kötter et al. 2009).

Outcome evaluation indicated an intervention effect on the main outcome criterion, i.e. children's emotional disruption at the end of the clinic stay (posttest) and six months later (follow-up) (Bühler and Kötter 2010). At follow-up, there was an intervention effect on internalizing and hyperactive behavior. Children whose mothers took part in the prevention program were rated as heving less emotional problems and less hyperactivity and inattention. Development of externalizing behaviors did not differ between the EFFEKT-E and the TAU comparison group. Regarding risk factors for maladaptive development, there was a short-term effect on problematic parenting but no effect on positive parenting. Parental sense of competence was influenced to the largest extent. EFFEKT-E mothers reported to be more self-efficacious and content in their parental role at posttest and follow-up. After the training, disturbed interaction - one factor of perceived parental stress - was significantly lower than in the comparison group. We did find a short-term intervention effect for children's social competence (Bühler and Kötter, 2010; Kötter et al. in press; Kötter et al. submitted). Effect sizes for children's behavior and disturbed interaction 
between mother and child are small and large for maternal sense of competence (Kötter et al. submitted).

Conclusions

A new prevention program for children of depressive mothers was developed on a sound theoretical and empirical basis. The family oriented approach focuses on important malleable risk factors for child development such as parenting behavior and beliefs, familial stress exposure, and children's social-cognitive skills (Goodman and Gotlib 2002; Garber 2006). A mediation analysis with the evaluation study baseline data supported the prevention model, i.e. perceived parenting stress and competence mediated the relationship of maternal depression and children's emotional and behavioral problems. The program has proven to attract the target group, to be accepted by mothers, children and trainers, and to be implementable in the routine practice of mother-childclinics. Finally, the program has shown various desirable effects. When mothers and children participated in the EFFEKT-E program offspring on average showed less emotional and hyperactive behavior problems. Conclusions are limited insofar as effects are based on motherreported data and cover a follow-up observation period of six months. In addition, the average effect sizes were not large. However, one must take into account that EFFEKT-E is a short intervention that was added to the much more intensive usual treatment in mother-child rehabilitation centers. Because the program is relatively easy to deliver in a group format, the findings of our evaluations are also encouraging with regard to cost-benefit issues. But at the end, an even longer-term follow up study would be necessary to prove whether a short term intervention like EFFEKT-E in a special setting without aftercare in daily life is able to favourably shape the developmental trajectory of a depressive disorder in children of depressed mothers.

\section{Acknowledgements}

The study was funded by the German Federal Ministry of Education and Research. We wish to thank the Bundesverband Arbeiterwohlfahrt and clinic staff for their cooperation and mothers and children for study participation.

\section{References}

Abidin RR (1995). Parenting Stress Index (3rd ed.). Psychological Assessment Resources., Odessa, FL

Beardslee W, Gladstone TRG, Wright EJ, Cooper AB (2003) A family-based approach to the prevention of depressive symptoms in children at risk: evidence of parental and child change. Pediatr 112:119-131 
Beardslee W, Salt P, Versage EM, Gladstone TRG, Wright EJ, Rothberg PC (1997) Sustained change in parents receiving preventive interventions for families with depression. Am $\mathbf{J}$ Psychiatry 154:510-515

Beeber LS, Cooper C, Van Nov BE, Schwartz TA, Blanchard HC, Canuso R, Robb K, Laudenbacher C, Emory, SL (2007) Flying under the radar: engagement and retention of depressed low-income mothers in a mental health intervention. Advances in Nursing Science 30:221-234

Beelmann A (2003) Wirksamkeit eines sozialen Problemlösetrainings bei entwicklungsverzögerten Vorschulkindern. Z Päd Psych 17:27-41

Beelmann A, Jaursch S, Lösel F (2007) IKPL - Ich kann Probleme lösen für Kinder von emotional belasteten Familien. Institut für Psychologie, Universität Erlangen-Nürnberg

Beelmann A, Lösel F (2004) Elterntraining zur Förderung der Erziehungskompetenz. Institut für Psychologie, Universität Erlangen-Nürnberg

Beelmann A, Lösel F, Jaursch S, Bühler A, Kötter C (2007) Elterntraining zur Förderung der Erziehungskompetenz für emotional belastete Familien. Institut für Psychologie, Universität Erlangen-Nürnberg

Bühler A, Kötter C (2010) Prävention der familialen Transmission der Depression bei Kindern depressiver Mütter. IFT Bericht, Institut für Therapieforschung, München

Clarke GN, Hornbrook M, Lynch F, Polen M, Gale J, Beardslee W et al (2001) A randomized trial of a group cognitive intervention for preventing depression in adolescent offspring of depressed parents. Arch Gen Psychiatry 58:1127-1134

Compas BE, Forehand R, Keller G, Champion JE, Rakow A, Reeslund KL, McKee L, Fear JM, Colletti CJ, Hardcastle E, Merchant MJ, Roberts L, Potts J, Garai E, Coffelt N, Roland E, Sterba SK, Cole DA. (2009) Randomized controlled trial of a family cognitive-behavioral preventive intervention for children of depressed parents. J Consult Clin Psychol. 77:1007-20

Compas BE, Champion JE, Forehand R, Cole DA, Reeslund KL, Fear J, Hardcastle EJ, Keller G, Rakow A, Garai E, Merchant MJ, Roberts L. (2010) Coping and parenting: Mediators of 12month outcomes of a family group cognitive-behavioral preventive intervention with families of depressed parents. J Consult Clin Psychol. 78:623-34

Döpfner M, Berner W, Fleischmann T, Schmidt MH (1993) Verhaltensbeurteilungsbogen für Vorschulkinder (VBV). Beltz, Weinheim

Garber J (2006) Depression in children and adolescents: Linking risk research and prevention. Am J Prev Med 31:104-125

Garber J, Dole D (2010) Intergenerational transmission of depression: A launch and grow model of change across adolescence. Development and Psychpathology 22:819-830

Goodman SH (2007) Depression in mothers. Ann Rev Clin Psychol 3:107-135

Goodman SH, Gotlib IH (1999) Risk for Psychopathology in the Children of Depressed Mothers: a Developmental Model for Understanding Mechanisms of Transmission. Psychol Rev $106: 458-490$ 
Goodman SH, Gotlib IH (2002) Transmission of risk to children of depressed parents: Integration and conclusions. In Goodman SH, Gotlib IH (eds) Children of depressed parents. APA, Washington, pp 307-326

Groen G, Petermann F (2002) Depressive Kinder und Jugendliche. Hogrefe, Göttingen

Hölling H, Erhart M, Ravens-Sieberer U, Schlack R (2007) Verhaltensauffälligkeiten bei Kindern und Jugendlichen. Bundesgesundheitsblatt 50:784-793

Jacobi F, Wittchen HU, Hölting C, Höfler M, Pfister H, Müller N, Lieb R (2004) Prevalence, comorbidity and correlates of mental disorders in the general population: results from the German Health Interview and Examination Survey (GHS). Psychol Med 34:597-611

Johnston C, Mash EJ (1989) A measures of parenting satisfaction and efficacy. Journal of Clinical Child Psychology 18:167-175

Kötter C, Bühler A, Jaursch S (2009) EFFEKT-E: Forschungsprojekt zur Prävention von Depression in Mutter-Kind-Kliniken. Theorie und Praxis der Sozialen Arbeit 60:374-380

Kötter C, Stemmler M, Bühler A, Lösel F (2010) Mütterliche Depressivität, Erziehung und kindliche Erlebens- und Verhaltensprobleme. Kindheit und Entwicklung 19:109-118

Kötter C, Stemmler M, Lösel F, Bühler A, Jaursch S (in press) Mittelfristige Effekte des Präventionsprogramms EFFEKT-E für emotional belastete Mütter und ihre Kinder unter besonderer Berücksichtigung psychosozialer Risikofaktoren. Z Gesundheitspsychologie

Lösel F, Beelmann A, Stemmler M, Jaursch S (2006) Prävention von Problemen des Sozialverhaltens im Vorschulalter: Evaluation des Eltern- und Kindertrainings EFFEKT. Z Klin Psychol Psychother 35:79-81

Lösel F, Stemmler M, Jaursch S, Beelmann A (2009) Universal prevention of antisocial development: Short- and long-term effects of a child- and parent-oriented program. MschrKrim 92: 289-308.

Meixner K (2004) Externe Qualitätsmessung in Mutter-Kind und Müttereinrichtungen. Unveröff. Diss., Wirtschafts- und Verhaltenswissenschaftliche Fakultät, Universität Freiburg

Pauschardt, J., Eimecke, S.D. \& Mattejat, F. (in press). Wer benötigt präventive Hilfen - wen erreichen wir? Zwei Rekrutierungswege für ein Projekt zur indizierten Prävention von introversiven Störungen bei Schulkindern. Z Gesundheitspsychologie.

Paykel ES, Brugha T, Fryers T (2005) Size and burden of depressive disorders in Europe. Eur Neuropsychopharmacol 15:411-423

Radloff LS (1977) The CES-D scale: A self-report depression scale for research in the general population. Appl Psychol Measurem 1:386-401

Reichle B, Gloger-Tippelt G (2007) Childhood social and emotional development in family contexts. Kindheit und Entwicklung 16:199-208

Runkel D (2009) EFFEKT-Interkulturell: Implementierung und Evaluation eines präventiven Eltern- und Kindertrainings an Grundschulen mit einem hohen Anteil von Kindern mit Migrationshindergrund. Doctoral Dissertation. Institute of Psychology, University of ErlangenNuremberg

Shelton KK, Frick PJ, Wootton J (1996) Assessment of Parenting Practices in Families of 
Elementary School-Age Children. Journal of Clinical Child Psychology 25:317-329

Stemmler M, Beelmann A, Jaursch S, Lösel F (2007) Improving parenting practices in order to prevent child behavior problems: A study on parent training as part of the EFFEKT. Int J Hyg Environ Health 210:563-570

Teti DM, O'Connell MA, Reiner CD (1996) Parenting Sensitivity, Parental Depression and Child Health: The Mediational Role of Parental Self-Efficacy. Early Development and Parenting 5:237-250

Tremblay RE, Vitaro F, Gagnon C, Piché C, Royer N (1992). A prosocial scale for the Preschool Behavior Questionnaire: Concurrent and predictive correlates. International Journal of Behavior Development 15:227-245 
Figure 1: Integrative Model for the Transmission of Risk to Children of Depressed Mothers (Goodman \& Gotlib, 1999, 2002) as a basis for development of EFFEKT-E

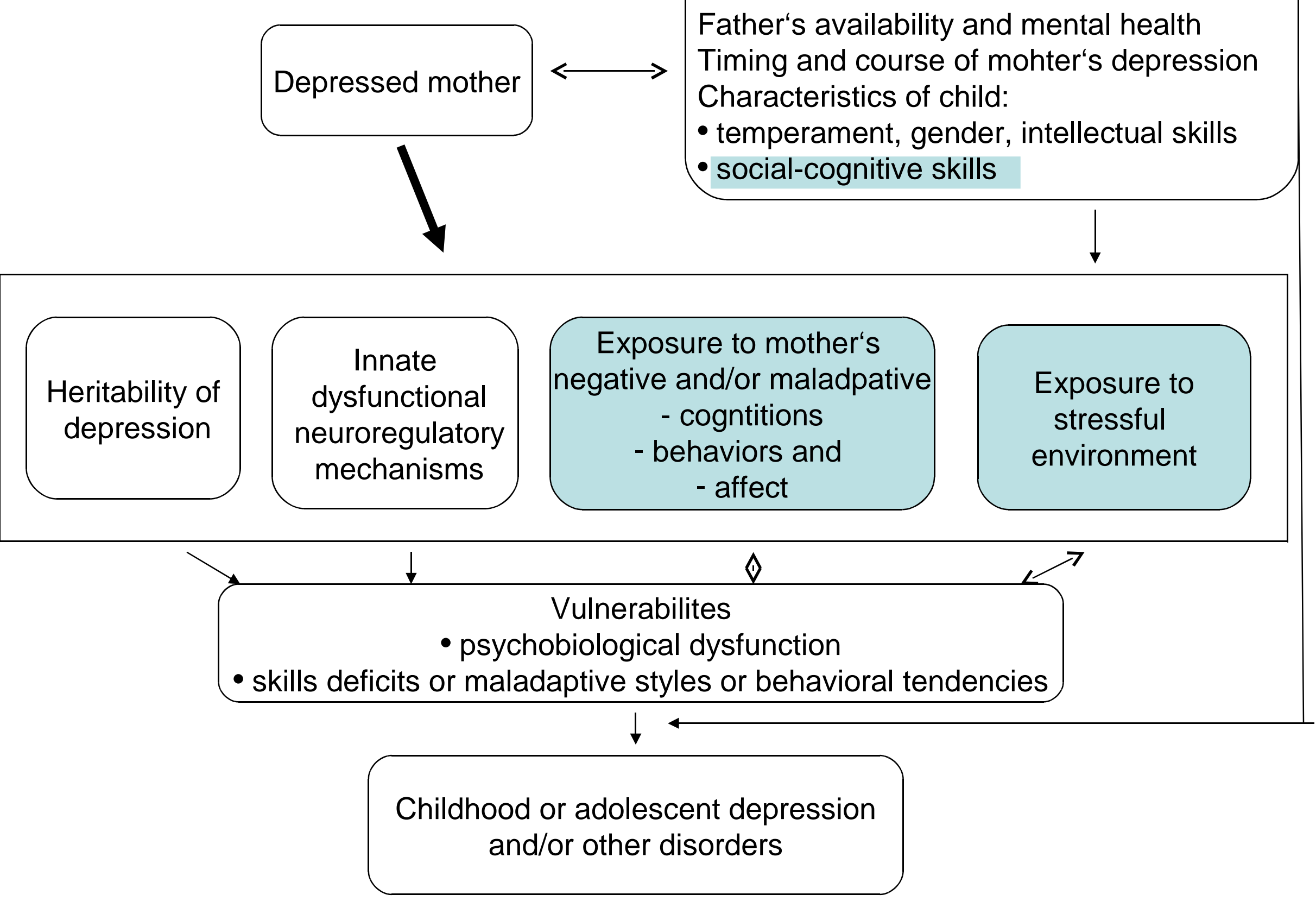


Figure 2: Evaluation study design

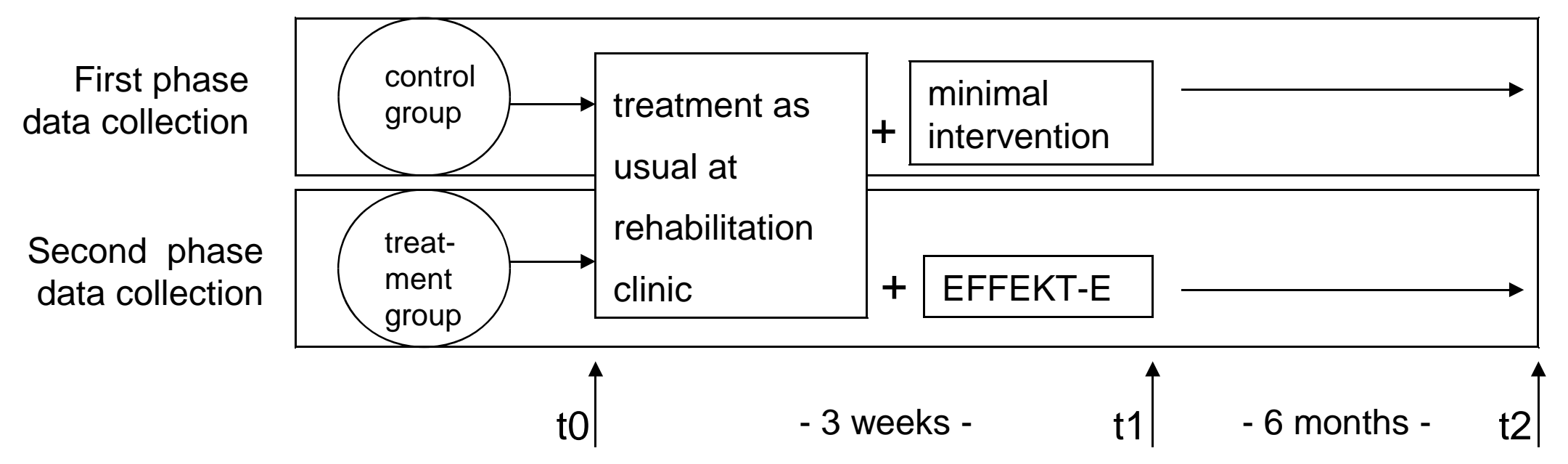


Table 1: Content of the EFFEKT-E parent training

\begin{tabular}{|c|c|}
\hline & Positive parenting rules \\
\hline & Giving attention to children's pleasant behaviors \\
\hline & Encouraging desirable behavior \\
\hline \multirow[t]{3}{*}{ Session 1: Positive Parenting } & Monitoring own parenting behavior \\
\hline & Identifying family rules \\
\hline & Asking for and requesting behaviors \\
\hline \multirow[t]{4}{*}{ Session 2: Family cooperation } & Cooperation enhancing techniques \\
\hline & Monitoring own parenting behavior \\
\hline & Rules for consistent parenting \\
\hline & Selecting consequences \\
\hline \multirow[t]{2}{*}{ Session 3: Consistent parenting } & Providing consequences \\
\hline & $\begin{array}{l}\text { Coping with stress and depression-specific mother- } \\
\text { child situations }\end{array}$ \\
\hline Session 4: Parental stress and strains & Education on child behavior problems \\
\hline (depression-specific) & Monitoring own coping behavior \\
\hline \multirow{4}{*}{$\begin{array}{l}\text { Session 5: Maternal role and beliefs } \\
\text { (depression-specific) }\end{array}$} & Challenging unhelpful thoughts about being a mother \\
\hline & Education on association between cognitions, emotions \\
\hline & and behavior \\
\hline & Identifying and seeking social support \\
\hline \multirow{3}{*}{$\begin{array}{l}\text { Session 6: Strengthening social } \\
\text { relationships }\end{array}$} & Promoting children's friendships \\
\hline & Problem solving in the family context \\
\hline & Promoting family cohesion \\
\hline
\end{tabular}

Table 2: Content of the EFFEKT-E child training

\begin{tabular}{ll}
\hline Session 1 & Preliminary, word-concepts and definitions \\
Session 2 & Emotions (happy, sad) \\
Session 3 & Emotions (anxious, angry, guilty) \\
Session 4 & Causality of actions (What happens next?) \\
Session 5 & Alternative solutions (What else could you try?) \\
Session 6 & Consequences of actions/ Evaluation of solutions \\
Session 7 & Exercising problem solving and communication in mother-child dyads \\
\hline
\end{tabular}

